\title{
PROJECTED CHANGES IN TEMPERATURE AND PRECIPITATION IN SARAWAK STATE OF MALAYSIA FOR SELECTED CMIP5 CLIMATE SCENARIOS
}

\author{
M. HUSSAIN ${ }^{1,2}$, K.W. YUSOF${ }^{2}$, M.R. MUSTAFA 2 , R. MAHMOOD ${ }^{3} \&$ J. SHAOFENG $^{3}$ \\ ${ }^{1}$ Hydro Department, Sarawak Energy Berhad, Kuching, Malaysia. \\ ${ }^{2}$ Department of Civil and Environmental Engineering, Universiti Teknologi Petronas, \\ Bandar Seri Iskandar, Malaysia. \\ ${ }^{3}$ Institute of Geographic Science and Natural Resources Research, \\ Chinese Academy of Sciences, Beijing, China.
}

\begin{abstract}
This article explores the projected changes in precipitation, maximum temperature $\left(\mathrm{T}_{\max }\right)$ and minimum temperature $\left(\mathrm{T}_{\min }\right)$ in the Malaysian state of Sarawak under Representative Concentration Pathways (RCPs) with the CanESM2 Global Circulation Model. The Statistical Downscaling Model (SDSM) was used to downscale these climate variables at three stations in Sarawak. The model performed well during the validation period and thus was used for future projections under three RCPs with the CanESM2 General Circulation Model. It is noted that the $\mathrm{T}_{\max }$ will increase by $1.94^{\circ} \mathrm{C}$ at Kuching, $0.09^{\circ} \mathrm{C}$ at Bintulu and $1.29^{\circ} \mathrm{C}$ at Limbang, when comparing the period of $2071-2100$ with the baseline period of 1981-2010, under the most robust scenario of RCP8.5. $\mathrm{T}_{\min }$ is also expected to increase by $1.21^{\circ} \mathrm{C}$ at Kuching, $0.15^{\circ} \mathrm{C}$ at Bintulu and $2.08^{\circ} \mathrm{C}$ at Limbang, under the RCP 8.5 projection for the same period. The precipitation at Kuching and Bintulu is expected to increase slightly to $1.6 \%$ and $1.4 \%$ at Kuching and Bintulu respectively; however, the seasonal shift is projected as follows: lesser precipitation during the December-February period and more during the June-August season. On the other hand, precipitation is expected to increase at Limbang during all seasons, when compared with the period of 1981-2010; it is expected that under RCP4.5 the annual precipitation at Limbang will increase by $10.5 \%$ during the $2071-2100$ period.
\end{abstract}

Keywords: Borneo, CanESM2, climate change, CMIP5 scenarios, Malaysia, NCEP, precipitation and temperature projection, Sarawak, statistical downscaling.

\section{INTRODUCTION}

Increased greenhouse gas (GHG) emissions and positive radiative forcing are the evidence of human impact on the global climate system. GHG emissions caused global surface warming, ranging from $0.5^{\circ} \mathrm{C}$ to $1.3^{\circ} \mathrm{C}$ during the years from 1951 to 2010 ; continued GHG emissions will cause further warming and change the equilibrium of the climate system, according to IPCC [1]. Under the projected future climate, it is plausible that grievous and extreme weather events (i.e. severe floods and droughts) will occur in global monsoon areas [2-5].

Temperature and precipitation are two main climate variables that influence the hydrological cycle as an impact of climate change. Global Climate Models, also called Global Circulation Models (GCMs), are the main tools for projecting the changes in temperature and precipitation. These models interpret global systems such as sea-ice, oceans and the atmosphere [6]. Although GCMs are very useful for the projection of future climate changes, the outputs of these models are based on a large grid scale (i.e. 250 to $600 \mathrm{~km}$ ). Because of their coarse resolution, the outputs cannot be used directly to investigate the environmental and hydrological impacts of climate change on a regional scale [7]. Therefore, for climate change impact studies, it is necessary to downscale GCMs' output to a regional or local scale.

Two main approaches are used to downscale the GCM output: statistical downscaling (SD) and dynamical downscaling (DD). The SD methods are much simpler than the DD methods; 
in the SD global scale, GCM climate variables, such as mean sea-level pressure, zonal wind, temperature, precipitation, geo-potential height etc., are linked with local-scale variables, such as observed temperature and precipitation, through various regression techniques for the controlled historical period. Then the future changes in local-scale temperature and precipitation are derived by forcing the future simulated data for selected GCM variables into the developed regression equations [8-11].

Many statistical models have been developed during recent years and have been used in various regions. The statistical downscaling model (SDSM) is also widely used to downscale the most important climate variables such as temperature and precipitation [12-16]. The objectives of this study are to derive an SD model using the SDSM toolbox for downscaling the precipitation, maximum temperature $\left(\mathrm{T}_{\max }\right)$ and minimum temperature $\left(\mathrm{T}_{\min }\right)$ in Sarawak and to assess the projected changes in precipitation, $\mathrm{T}_{\max }$ and $\mathrm{T}_{\min }$ under the representative concentration pathways (RCPs) of CanESM2 for the periods, 2011-2040, 2041-2070 and 2071-2100.

\section{STUDY AREA AND DATA DESCRIPTION}

Sarawak is the largest state of Malaysia $\left(124,450 \mathrm{Km}^{2}\right)$, located on Borneo Island in South East Asia. It experiences a wet and humid tropical climate throughout the year, with annual precipitation of between $2800 \mathrm{~mm}$ and $5000 \mathrm{~mm}$ and temperature variations between $20^{\circ} \mathrm{C}$ and $36^{\circ} \mathrm{C}$. In this study, three cities, i.e. Limbang, Bintulu and Kuching, in the northern, central and western regions, respectively, have been selected for the exploration of potential changes in temperature and precipitation. Most of the state's population is settled along the coast, and therefore the historical temperature record is only available at the airports in these coastal cities. The observed daily data of precipitation, $\mathrm{T}_{\max }$ and $\mathrm{T}_{\min }$ was collected from the Department of Irrigation and Drainage, Sarawak (DID) for three climate stations, as described in Table 1 and shown in Fig. 1.

The Canadian Centre for Climate Modelling and Analysis (CCCma) has developed a number of climate models. These are used to study climate change and its variability and to

Table 1: Geographical location, altitude and climate variables used for the selected meteorological stations in the Malaysian state of Sarawak.

\begin{tabular}{|c|c|c|c|c|}
\hline \multirow[b]{2}{*}{ Station } & \multicolumn{2}{|c|}{ Location } & \multirow[b]{2}{*}{$\begin{array}{l}\text { Altitude } \\
\text { (masl) }\end{array}$} & \multirow[b]{2}{*}{$\begin{array}{l}\text { Climate } \\
\text { Variables }\end{array}$} \\
\hline & $\begin{array}{l}\text { Latitude } \\
(\mathrm{D}, \mathrm{M}, \mathrm{S})\end{array}$ & $\begin{array}{l}\text { Longitude } \\
(\mathrm{D}, \mathrm{M}, \mathrm{S})\end{array}$ & & \\
\hline Kuching & 0012927 & 1102057 & 25 & $\begin{array}{c}\text { Precipitation } \\
\qquad \mathrm{T}_{\max } \\
\mathrm{T}_{\min }\end{array}$ \\
\hline Bintulu & 0030715 & 1130117 & 34 & $\begin{array}{c}\text { Precipitation } \\
\mathrm{T}_{\max } \\
\mathrm{T}_{\min }\end{array}$ \\
\hline Limbang & 0044446 & 1145958 & 15 & $\begin{array}{c}\text { Precipitation } \\
\mathrm{T}_{\max } \\
\mathrm{T}_{\min }\end{array}$ \\
\hline
\end{tabular}




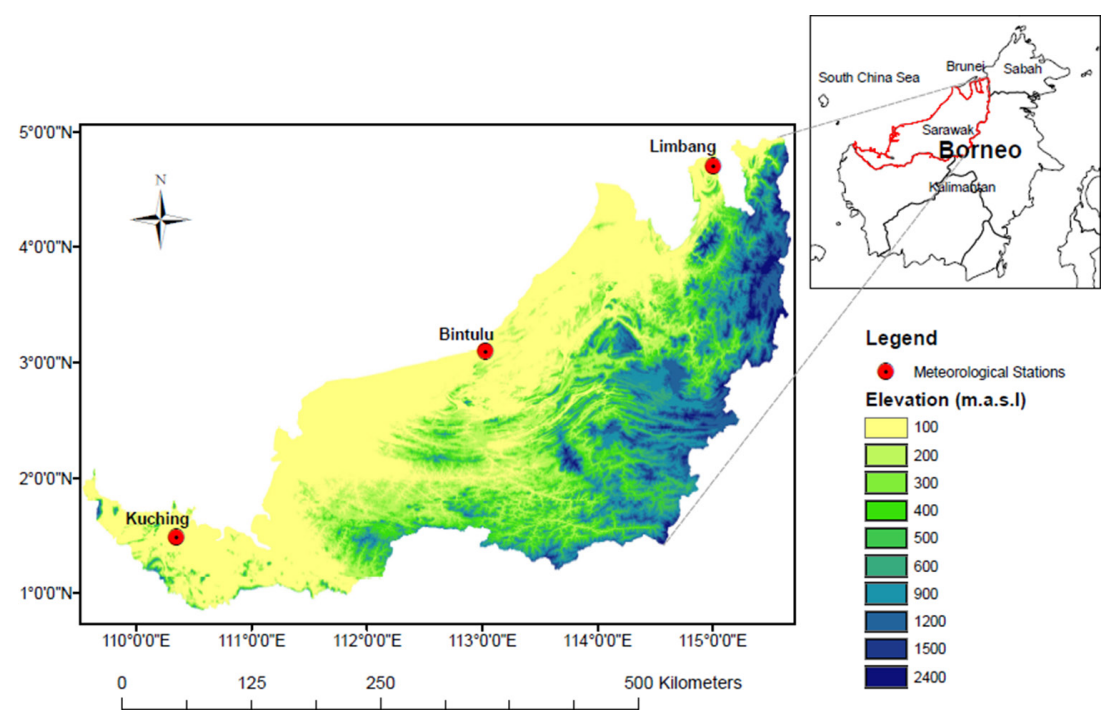

Figure 1: Location map of the selected meteorological stations in the Malaysian state of Sarawak.

understand the various processes that govern the global climate system. These models are also used to make quantitative projections of future long-term climate change under various GHG and aerosol forcing scenarios. In this study, two types of daily climate variables were obtained from the Canadian Climate Data and Scenarios website (http://ccds-dscc.ec.gc. ca/?page=dst-sdi): (a) 26 variables of the National Center of Environmental Prediction (NCEP) for the period 1981-2005, and (b) 26 variables of CanESM2 from CCCma for the historical period 1981-2005, as well as for the future period, 2006-2100, for three RCPs, i.e. RCP2.6, RCP4.5 and RCP8.5. These RCPs were developed by different modelling groups and address the different scenarios of future GHG emission scenarios. The RCP2.6 scenario leads to a very low level of GHG concentration. The RCP4.5 is a stabilization scenario, in which total radiative forcing is stabilized before 2100 by adopting various technologies and policies for minimizing the GHG emissions. The RCP8.5 scenario is categorized by increasing GHG emissions over time, leading to a high level of GHG concentration levels. The list of the NCEP and CanESM2 climate variables used in this study is shown in Table 2. All data used is available at a grid resolution of $2.8125^{\circ} \times 2.8125^{\circ}$ (Latitude $\times$ Longitude).

\section{METHODOLGY}

\subsection{Statistical downscaling model (SDSM)}

The SDSM is a downscaling tool developed by [17]; it combines multiple linear regression (MLR) with a stochastic weather generator (SWG). MLR establishes a statistical relationship between GCM predictor variables and local-scale predictands' variables to produce regression parameters. These calibrated regression parameters are further used with NCEP and GCM predictor variables in SWG to simulate daily time series to create a better correlation with the observed predictands' time series. 
Table 2: List of NCEP and CanESM2 climate variables used in this study.

\begin{tabular}{|c|c|c|c|c|c|}
\hline $\begin{array}{l}\text { Sr. } \\
\text { No. }\end{array}$ & Predictor & Description & $\begin{array}{l}\text { Sr. } \\
\text { No. }\end{array}$ & Predictor & Description \\
\hline 1 & temp & Mean temperature at $2 \mathrm{~m}$ & 14 & p1_zh & Divergence at surface \\
\hline 2 & mslp & Mean sea level pressure & 15 & p5_f & $\begin{array}{l}\text { Geostrophic air flow velocity } \\
\text { at } 500 \mathrm{hPa}\end{array}$ \\
\hline 3 & p500 & $\begin{array}{l}500 \mathrm{hPa} \text { geopotential } \\
\text { height }\end{array}$ & 16 & p5_z & Vorticity at $500 \mathrm{hPa}$ \\
\hline 4 & $\mathrm{p} 850$ & $\begin{array}{l}850 \mathrm{hPa} \text { geopotential } \\
\text { height }\end{array}$ & 17 & p5_u & $\begin{array}{l}\text { Zonal velocity component at } \\
500 \mathrm{hPa}\end{array}$ \\
\hline 5 & r500 & $\begin{array}{l}\text { Relative humidity at } 500 \\
\text { hPa height }\end{array}$ & 18 & p5_v & $\begin{array}{l}\text { Meridional velocity } \\
\text { component at } 500 \mathrm{hPa}\end{array}$ \\
\hline 6 & r850 & $\begin{array}{l}\text { Relative humidity at } 850 \\
\mathrm{hPa} \text { height }\end{array}$ & 19 & p5_th & Wind direction at $500 \mathrm{hPa}$ \\
\hline 7 & shum & $\begin{array}{l}\text { Near surface specific } \\
\text { humidity }\end{array}$ & 20 & p5_zh & Divergence at $500 \mathrm{hPa}$ \\
\hline 8 & prec & Total precipitation & 21 & p8_f & $\begin{array}{l}\text { Geostrophic air flow velocity } \\
\text { at } 850 \mathrm{hPa}\end{array}$ \\
\hline 9 & p1_f & $\begin{array}{l}\text { Geostrophic air flow } \\
\text { velocity at surface }\end{array}$ & 22 & p8_z & Vorticity at $850 \mathrm{hPa}$ \\
\hline 10 & p1_z & Vorticity at surface & 23 & p8_u & $\begin{array}{l}\text { Zonal velocity component at } \\
850 \mathrm{hPa}\end{array}$ \\
\hline 11 & p1_u & $\begin{array}{l}\text { Zonal velocity component } \\
\text { at surface }\end{array}$ & 24 & p8_v & $\begin{array}{l}\text { Meridional velocity } \\
\text { component at } 850 \mathrm{hPa}\end{array}$ \\
\hline 12 & $\mathrm{p} 1 \_\mathrm{v}$ & $\begin{array}{l}\text { Meridional velocity } \\
\text { component at surface }\end{array}$ & 25 & p8_th & Wind direction at $850 \mathrm{hPa}$ \\
\hline 13 & p1_th & Wind direction at surface & 26 & p8_zh & Divergence at $850 \mathrm{hPa}$ \\
\hline
\end{tabular}

There are three kinds of sub-models - monthly, seasonal and annual sub-models - that comprise the statistical/empirical relationship between the regional-scale variables (temperature and precipitation) and large-scale variables. Annual sub-models derive a single regression equation for all months in the year, seasonal sub-models derive a regression equation for each season, and the monthly sub-model represents a separate regression equation for each month.

There are also two options within sub-models: conditional and unconditional sub-models. The conditional sub-models are used for the parameters that are dependent on the occurrence of other climate parameters, i.e. precipitation, evaporation, etc., while the unconditional models are used for independent climate parameters, i.e. temperature $[15,17]$. SDSM also contains a tool to normalize the input climate data prior to its usage in the regression equations.

\subsection{Screening of predictors}

In SDSM, the most suitable variables from the atmospheric predictors are selected through a MLR model, utilizing the combination of the correlation matrix, partial correlation, P-value, 
histograms, and scatter plots. In the current study, a correlation analysis was applied between predictands and NCEP predictors; each predictor was selected based on the highest correlation, partial correlation and least $\mathrm{P}$-value with the predictand (precipitation, $\mathrm{T}_{\max }$ and $\left.\mathrm{T}_{\min }\right)$. At Kuching, prec was the super predictor with higher rank for precipitation, temp for $\mathrm{T}_{\max }$ and shum for $\mathrm{T}_{\min }$. At Bintulu, prec was the super predictor for precipitation, $\mathrm{p} 1 \mathrm{Z}$ for $\mathrm{T}_{\max }$ and $\mathrm{p} 500$ for $\mathrm{T}_{\text {min }}$. At Limbang, prec was the super predictor for precipitation, temp for $\mathrm{T}_{\max }$ and $\mathrm{p} 500$ for $\mathrm{T}_{\text {min }}$. In general, the selection of predictor variables in this study was performed in a similar way to those applied in other studies, for example $[14,18]$.

\subsection{Model calibration and validation}

Based on the available observed data, two daily data sets, 1981-1995 and 1996-2005, were selected for the model calibration and validation, respectively. Daily downscaling models were developed in SDSM for precipitation, $\mathrm{T}_{\max }$ and $\mathrm{T}_{\min }$ to generate the separate regression equation for each month. The conditional sub-model is used for $\mathrm{T}_{\max }$ and $\mathrm{T}_{\min }$ without any transformation and the unconditional sub-model, for precipitation. Optimization of the best fit is performed by the ordinary Least Squares (OLS) method. The correlation coefficient (R) and root mean square error (RMSE) of simulated data to observed data were used as performance indicators during the calibration and validation. With the calibrated model for the period of 1981-1995, 20 daily ensembles for precipitation, $\mathrm{T}_{\max }$ and $\mathrm{T}_{\min }$ were simulated for the period of 1996-2005, feeding the NCEP and CanESM2 predictors, and the mean ensemble of these 20 ensembles was used for validation with the observed data for the same period (1996-2005).

During the calibration, at all stations, the model simulated daily precipitation, $\mathrm{T}_{\max }$ and $\mathrm{T}_{\text {min }}$ well; however, it overestimated the daily precipitation at all stations. The performance of the model during the calibration period simulated by SDSM (using the NCEP variables) is shown in Table 3. This over-estimation of precipitation was addressed during the validation period, when these biases were calculated and daily precipitation was de-biased as explained in Section 3.4. Kuching's temperature and precipitation have better correlation during the calibration period, as compared to Bintulu and Limbang, the latter of which shows the lowest correlation. For the coefficient of correlation, the model performed better for $\mathrm{T}_{\max }$ as compared to $\mathrm{T}_{\min }$ and precipitation. During the calibration period, while comparing the coefficient of correlation, the SDSM performance is similar to that shown in [14], when applied to Peninsular Malaysia.

During the validation period, the precipitation, $\mathrm{T}_{\max }$ and $\mathrm{T}_{\min }$ were simulated using the NCEP data, as well as the CanESM2 historical data, to evaluate the model performance with both data sets. Table 4 shows the model's performance during the validation period. The model simulated average daily and monthly $\mathrm{T}_{\max }$ and $\mathrm{T}_{\min }$ very well at all stations. Compared to the observed daily/monthly precipitation, the simulated monthly precipitation was slightly higher at Kuching and Bintulu and slightly lower at Limbang. In order to remove the errors, during validation, the biases were adjusted by the bias-correction method, as shown in Fig. 2. The model performed well for temperature downscaling at all three stations in Sarawak; however, for the precipitation downscaling, the model performance was fairly satisfactory and could be improved further with some alternative methods/models.

\subsection{Bias correction}

Bias correction (BC) has been used in several studies, such as [12, 13], to remove biases from the daily precipitation and temperature series of downscaled data. The techniques for bias 
Table 3: Performance of model for daily and monthly time series of $\mathrm{T}_{\max }, \mathrm{T}_{\min }$ and precipitation during the calibration period (1981-1995).

\begin{tabular}{|c|c|c|c|c|c|c|c|c|c|}
\hline & \multicolumn{3}{|c|}{$\mathrm{T}_{\max }$} & \multicolumn{3}{|c|}{$\mathrm{T}_{\text {min }}$} & \multicolumn{3}{|c|}{ Precipitation } \\
\hline & $\mathrm{X}$ & $\mathrm{R}$ & RMSE & $\mathrm{X}$ & $\mathrm{R}$ & RMSE & $X$ & $\mathrm{R}$ & RMSE \\
\hline & $\left({ }^{\circ} \mathrm{C}\right)$ & & & $\left({ }^{\circ} \mathrm{C}\right)$ & & & $(\mathrm{mm})$ & & \\
\hline \multicolumn{10}{|c|}{ Western Region (Kuching) } \\
\hline \multicolumn{10}{|l|}{ Daily } \\
\hline Obs & 31.60 & & & 23.09 & & & 11.26 & & \\
\hline NCEP & 31.59 & 0.66 & 1.24 & 23.16 & 0.49 & 0.55 & 13.48 & 0.28 & 19.85 \\
\hline \multicolumn{10}{|c|}{ Monthly } \\
\hline Obs & 31.60 & & & 23.09 & & & 342.6 & & \\
\hline NCEP & 31.60 & 0.87 & 0.50 & 23.09 & 0.74 & 0.21 & 406.5 & 0.74 & 115.4 \\
\hline \multicolumn{10}{|c|}{ Central Region (Bintulu) } \\
\hline \multicolumn{10}{|c|}{ Daily } \\
\hline Obs & 30.90 & & & 23.61 & & & 9.94 & & \\
\hline NCEP & 30.98 & 0.54 & 1.25 & 23.70 & 0.34 & 0.75 & 12.22 & 0.18 & 20.08 \\
\hline \multicolumn{10}{|c|}{ Monthly } \\
\hline Obs & 30.89 & & & 23.61 & & & 302.3 & & \\
\hline NCEP & 30.90 & 0.73 & 0.35 & 23.60 & 0.58 & 0.26 & 361.1 & 0.59 & 110.3 \\
\hline \multicolumn{10}{|c|}{ Northern Region (Limbang) } \\
\hline \multicolumn{10}{|c|}{ Daily } \\
\hline Obs & 32.30 & & & 23.30 & & & 7.33 & & \\
\hline NCEP & 32.41 & 0.28 & 1.70 & 23.28 & 0.20 & 1.03 & 8.95 & 0.19 & 14.78 \\
\hline \multicolumn{10}{|c|}{ Monthly } \\
\hline Obs & 32.30 & & & 23.23 & & & 222.9 & & \\
\hline NCEP & 32.29 & 0.49 & 0.76 & 23.22 & 0.38 & 0.53 & 260.1 & 0.49 & 85.59 \\
\hline
\end{tabular}

correction for temperature differ from those for precipitation, and the following equations are used to correct the biases in the daily time series of temperature and precipitation:

$$
\begin{gathered}
T_{d e b}=T_{S C E N}-\left(\overline{T_{C O N T}}-\overline{T_{o b s}}\right) \\
P_{d e b}=P_{S C E N} \times\left(\overline{\left.\frac{P_{o b s}}{\overline{P_{C O N T}}}\right)}\right.
\end{gathered}
$$

where $\mathrm{T}_{\mathrm{deb}}$ and $\mathrm{P}_{\mathrm{deb}}$ are the de-biased (corrected) daily time series of temperature (in ${ }^{\circ} \mathrm{C}$ ) and precipitation (in $\mathrm{mm} /$ day), respectively, for future periods. SCEN represents the scenario data downscaled by SDSM for future periods (e.g., 2011-2040 etc.), and CONT represents data downscaled by SDSM for the historical controlled period (e.g. 1981-1995). $\mathrm{T}_{\text {SCEN }}$ and $\mathrm{P}_{\text {SCEN }}$ are the daily time series of temperature and precipitation generated by SDSM for future 
Table 4: Performance of SDSM models for simulating $\mathrm{T}_{\max }, \mathrm{T}_{\min }$ and precipitation during validation (1996-2005).

\begin{tabular}{|c|c|c|c|c|c|c|c|c|c|}
\hline & \multicolumn{3}{|c|}{$\mathrm{T}_{\max }$} & \multicolumn{3}{|c|}{$\mathrm{T}_{\text {min }}$} & \multicolumn{3}{|c|}{ Precipitation } \\
\hline & $X$ & $\mathrm{R}$ & RMSE & $X$ & $\mathrm{R}$ & RMSE & $X$ & $\mathrm{R}$ & RMSE \\
\hline & ${ }^{\circ} \mathrm{C}$ & & & ${ }^{\circ} \mathrm{C}$ & & & $\mathrm{mm}$ & & \\
\hline \multicolumn{10}{|c|}{ Western Region (Kuching) } \\
\hline \multicolumn{10}{|l|}{ Daily } \\
\hline Obs & 31.60 & & & 23.37 & & & 11.46 & & \\
\hline NCEP & 31.60 & 0.60 & 1.27 & 23.37 & 0.38 & 0.59 & 11.48 & 0.17 & 22.28 \\
\hline CanESM2 & 31.60 & 0.51 & 1.37 & 23.38 & 0.18 & 0.69 & 11.49 & 0.15 & 22.85 \\
\hline \multicolumn{10}{|l|}{ Montly } \\
\hline Obs & 31.60 & & & 23.37 & & & 348.9 & & \\
\hline NCEP & 31.74 & 0.87 & 0.55 & 23.03 & 0.62 & 0.45 & 375.9 & 0.66 & 166.5 \\
\hline CanESM2 & 31.36 & 0.83 & 0.64 & 22.94 & 0.48 & 0.55 & 385.5 & 0.61 & 176.2 \\
\hline \multicolumn{10}{|c|}{ Central Region (Bintulu) } \\
\hline \multicolumn{10}{|l|}{ Daily } \\
\hline Obs & 31.19 & & & 23.84 & & & 10.26 & & \\
\hline NCEP & 31.19 & 0.30 & 1.89 & 23.84 & 0.27 & 0.83 & 10.28 & 0.15 & 20.57 \\
\hline CanESM2 & 31.19 & 0.30 & 1.89 & 23.84 & 0.12 & 0.90 & 10.29 & 0.02 & 21.15 \\
\hline \multicolumn{10}{|l|}{ Monthly } \\
\hline Obs & 31.19 & & & 23.84 & & & 312.4 & & \\
\hline NCEP & 30.89 & 0.76 & 0.60 & 23.54 & 0.50 & 0.40 & 313.0 & 0.48 & 135.2 \\
\hline CanESM2 & 30.89 & 0.77 & 0.60 & 23.64 & 0.43 & 0.45 & 325.3 & 0.28 & 150.4 \\
\hline \multicolumn{10}{|c|}{ Northern Region (Limbang) } \\
\hline \multicolumn{10}{|l|}{ Daily } \\
\hline Obs & 33.14 & & & 23.54 & & & 9.34 & & \\
\hline NCEP & 33.14 & 0.29 & 1.25 & 23.54 & 0.07 & 0.92 & 9.34 & 0.10 & 17.79 \\
\hline CanESM2 & 33.14 & 0.29 & 1.26 & 23.55 & 0.18 & 0.90 & 9.34 & 0.01 & 18.17 \\
\hline \multicolumn{10}{|l|}{ Montly } \\
\hline Obs & 33.13 & & & 23.54 & & & 284.2 & & \\
\hline NCEP & 32.35 & 0.53 & 1.04 & 22.97 & 0.13 & 0.73 & 245.1 & 0.37 & 138.1 \\
\hline CanESM2 & 32.19 & 0.55 & 1.17 & 23.24 & 0.60 & 0.46 & 233.4 & 0.19 & 150.4 \\
\hline
\end{tabular}

periods, respectively. TCONT and PCONT are the mean monthly values for temperature and precipitation, respectively, for the control period (historical) simulated by SDSM. $\mathrm{T}_{\text {obs }}$ and $\mathrm{P}_{\mathrm{obs}}$ represent the long-term mean monthly observed values for temperature and precipitation. The bar on $\mathrm{T}$ and $\mathrm{P}$ shows the long-term average. Table 5 presents the monthly standard deviation of observed and simulated data at Kuching for the period, 2071-2100. It demonstrates that the model successfully generated the future time series of temperature and precipitation realistically. 

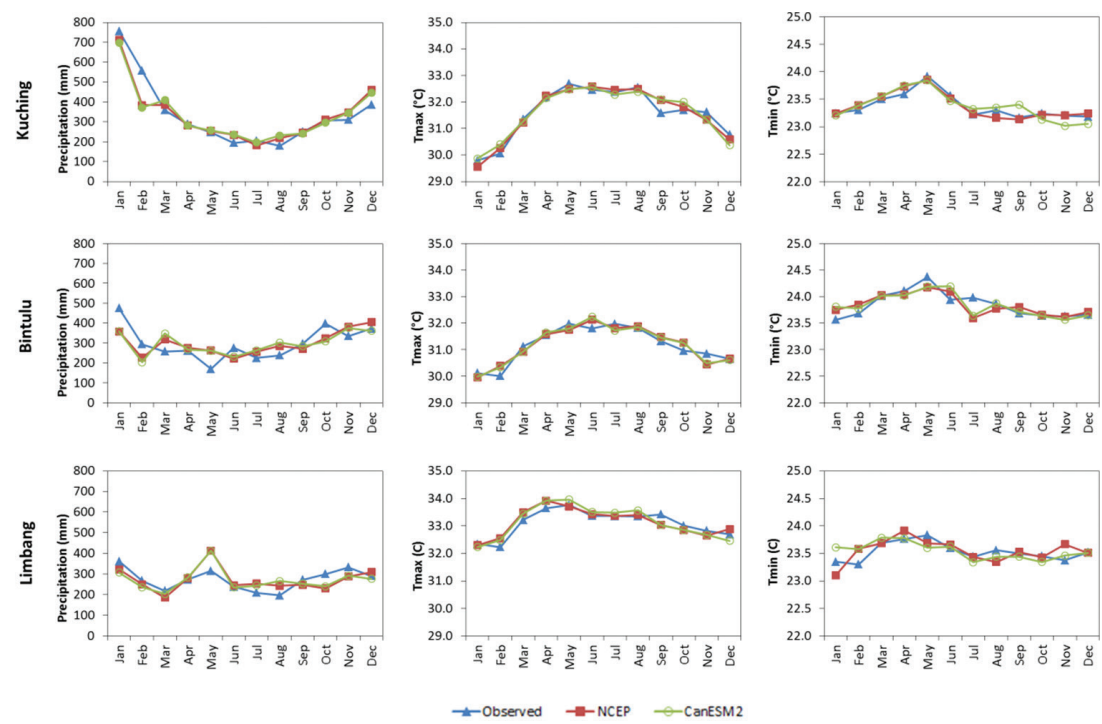

Figure 2: Comparison of monthly precipitation, $\mathrm{T}_{\max }$ and $\mathrm{T}_{\min }$ simulated by SDSM with observed dataset during validation period (with bias correction) in the Malaysian state of Sarawak.

Table 5: Standard deviation of observed and simulated monthly precipitation, $\mathrm{T}_{\max }$ and $\mathrm{T}_{\min }$ at Kuching.

\begin{tabular}{lccccc}
\hline & Historical & & RCP2.6 & RCP4.5 & RCP8.5 \\
\cline { 2 - 3 } \cline { 5 - 6 } Variable & $1981-2010$ & & & $2071-2100$ & \\
\hline Precipitation & 194 & & 134 & 135 & 134 \\
$\mathrm{~T}_{\max }$ & 1.6 & & 1.12 & 1.16 & 1.30 \\
$\mathrm{~T}_{\min }$ & 0.6 & & 0.31 & 0.35 & 0.50 \\
\hline
\end{tabular}

\section{RESULTS AND DISCUSSIONS}

\subsection{Annual changes in precipitation and temperature}

Feeding the selected CanESM2 predictors of three future scenarios, i.e. RCP2.6, RCP4.5 and RCP8.5 into developed SDSM models, daily precipitation, $\mathrm{T}_{\max }$ and $\mathrm{T}_{\min }$ were simulated for three future periods: 2011-2040, 2041-2070 and 2071-2100. BC was applied as calculated during the control period (1981-2005) to remove biases in the projected data. Future changes in precipitation, $\mathrm{T}_{\max }$ and $\mathrm{T}_{\text {min }}$ were calculated by comparing them to the baseline period. In this study, the period from 1981 to 2010 was selected as the baseline period because this 30 -year period has been used in the majority of climate change studies across the world $[5,19,20]$. A 30 -year period is considered sufficient to define the local climate, as it is 
anticipated that it will comprise different situations such as dry, wet, cool, and warm years or sub-periods.

As the RCP8.5 is the scenario considering a high concentration of GHG emissions, it is noted that the mean annual $\mathrm{T}_{\max }$ at Kuching would be expected to increase by $1.94^{\circ} \mathrm{C}$ during 2080 's under the RCP8.5 scenario. At Bintulu, $\mathrm{T}_{\max }$ is expected to increase by $0.09^{\circ} \mathrm{C}$ during the 2080s. At Limbang, the $\mathrm{T}_{\max }$ would also increase by $1.29^{\circ} \mathrm{C}$ during the $2080 \mathrm{~s}$. The $\mathrm{T}_{\min }$ also followed the same pattern as of that of the $\mathrm{T}_{\max }$ and would be expected to increase by $1.21^{\circ} \mathrm{C}$ at Kuching, $0.15^{\circ} \mathrm{C}$ at Bintulu and $2.08^{\circ} \mathrm{C}$ at Limbang during the 2080 s, when compared with the baseline period. In future, the annual precipitation at Kuching, Bintulu and Limbang is expected to increase by $0.3 \%, 1.4 \%$ and $4.5 \%$, respectively, during the $2080 \mathrm{~s}$, as shown in Table 4 . The projection of precipitation, $\mathrm{T}_{\max }$ and $\mathrm{T}_{\min }$ during the 2020s, 2050s and 2080s under the RCP2.6, RCP4.5 and RCP8.5 is detailed in Table 6.

\subsection{Seasonal changes in precipitation and temperature}

The temperature in Sarawak has the same pattern throughout the year, with December to February (DJF) having heavy rainfall and slightly lower temperatures, as compared to the other seasons. The precipitation changes over the seasons; during DJF, Sarawak receives its highest rainfall due to the north-west monsoons, while June to August (JJA) are the lowest precipitation months. The other two seasons, i.e. March to May (MAM) and September to November (SON), are the inter-monsoon months and give average precipitation. The changes in future seasonal precipitation, $\mathrm{T}_{\max }$ and $\mathrm{T}_{\min }$ were calculated under the three RCPs of CanESM2, and the future period of 2071-2100 was compared with the baseline period of 1981-2010.

During the drier season of JJA, it is noted that, during 2071-2100, surface $\mathrm{T}_{\max }$ would increase to $1.06^{\circ} \mathrm{C}, 1.44^{\circ} \mathrm{C}$ and $2.21^{\circ} \mathrm{C}$ at Kuching, to $0.17^{\circ} \mathrm{C}, 0.18^{\circ} \mathrm{C}$ and $0.18^{\circ} \mathrm{C}$ at Bintulu

Table 6: Future changes in annual precipitation, $\mathrm{T}_{\max }$ and $\mathrm{T}_{\min }$ with respect to the baseline (1981-2010) under CanESM2 runs for possible future RCP scenarios.

\begin{tabular}{|c|c|c|c|c|c|c|c|c|c|}
\hline & \multicolumn{3}{|c|}{ Kuching } & \multicolumn{3}{|c|}{ Bintulu } & \multicolumn{3}{|c|}{ Limbang } \\
\hline & 2020’s & 2050’s & 2080’s & 2020’s & 2050’s & 2080’s & 2020’s & 2050’s & 2080’s \\
\hline \multicolumn{10}{|c|}{$\mathrm{T}_{\max }\left({ }^{\circ} \mathrm{C}\right)$} \\
\hline $\mathrm{RCP} 2.6$ & 0.68 & 0.88 & 0.85 & 0.08 & 0.10 & 0.10 & 0.71 & 0.79 & 0.78 \\
\hline RCP4.5 & 0.66 & 1.04 & 1.20 & 0.09 & 0.10 & 0.09 & 0.70 & 0.87 & 0.94 \\
\hline RCP8.5 & 0.76 & 1.27 & 1.94 & 0.09 & 0.09 & 0.09 & 0.75 & 0.98 & 1.29 \\
\hline \multicolumn{10}{|l|}{$\mathrm{T}_{\min }\left({ }^{\circ} \mathrm{C}\right)$} \\
\hline $\mathrm{RCP} 2.6$ & 0.51 & 0.60 & 0.58 & 0.13 & 0.15 & 0.14 & 0.64 & 0.88 & 0.83 \\
\hline RCP4.5 & 0.51 & 0.70 & 0.78 & 0.13 & 0.14 & 0.15 & 0.66 & 1.02 & 1.19 \\
\hline RCP8.5 & 0.54 & 0.84 & 1.21 & 0.14 & 0.14 & 0.15 & 0.72 & 1.36 & 2.08 \\
\hline \multicolumn{10}{|c|}{ Precipitation (\%) } \\
\hline RCP2.6 & 1.3 & 1.3 & -0.1 & 1.0 & -0.6 & -0.3 & 10.1 & 8.2 & 9.9 \\
\hline $\mathrm{RCP} 4.5$ & 0.5 & 0.9 & 1.6 & -0.4 & 0.3 & 1.0 & 9.3 & 9.5 & 10.5 \\
\hline RCP8.5 & 1.4 & 1.1 & 0.3 & 0.1 & 1.6 & 1.4 & 10.0 & 7.6 & 4.5 \\
\hline
\end{tabular}



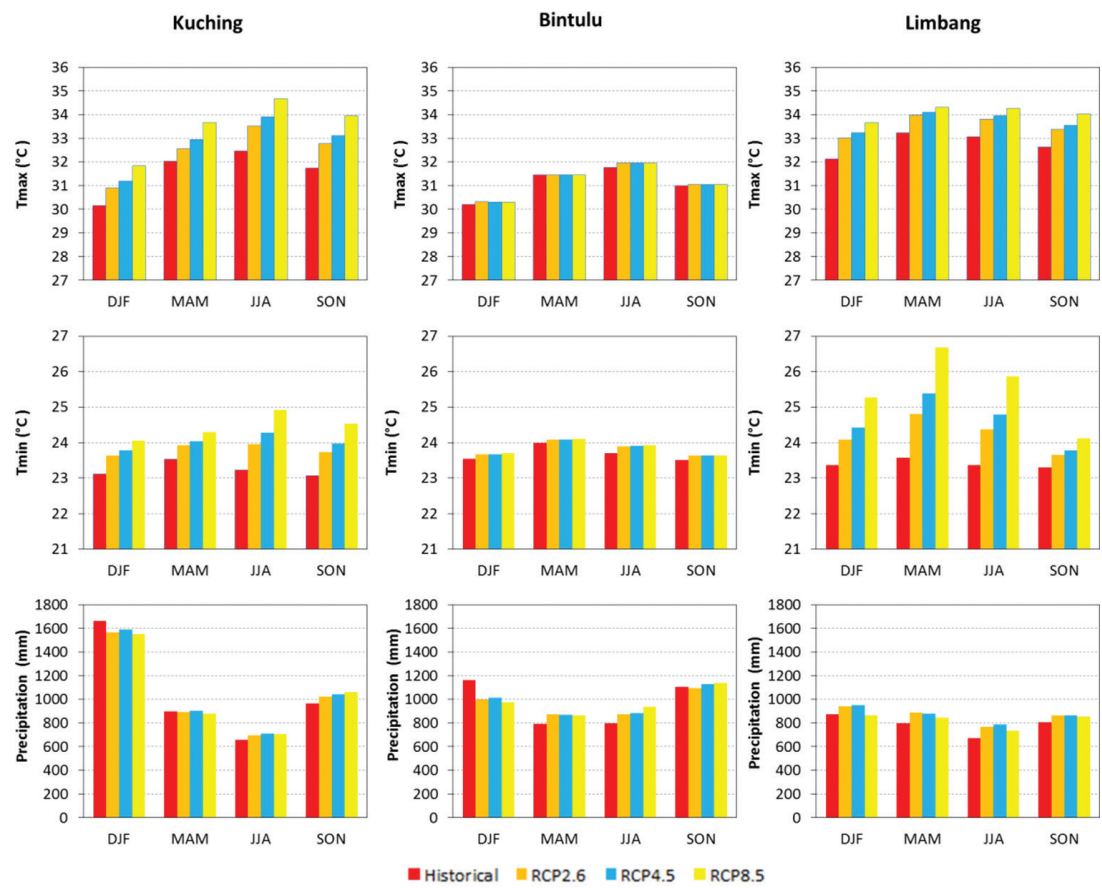

Figure 3: Seasonal changes in $\mathrm{T}_{\max }, \mathrm{T}_{\min }$ and precipitation at three stations for the period of 2071-2100, compared to the baseline period of 1981-2010.

Table 7: Future projected changes in seasonal precipitation, $\mathrm{T}_{\max }$ and $\mathrm{T}_{\min }$ during the period, 2071-2100, with respect to the baseline (1981-2010) under CanESM2 runs for possible future RCP scenarios.

\begin{tabular}{|c|c|c|c|c|c|c|c|c|c|c|c|c|}
\hline & \multicolumn{4}{|c|}{$\mathrm{RCP} 2.6$} & \multicolumn{4}{|c|}{$\mathrm{RCP} 4.5$} & \multicolumn{4}{|c|}{ RCP8.5 } \\
\hline & DJF & MAM & JJA & SON & DJF & MAM & JJA & SON & DJF & MAM & JJA & SON \\
\hline \multicolumn{13}{|l|}{$\mathrm{T}_{\max }\left({ }^{\circ} \mathrm{C}\right)$} \\
\hline Kuching & 0.74 & 0.54 & 1.06 & 1.04 & 1.03 & 0.92 & 1.44 & 1.39 & 1.68 & 1.63 & 2.21 & 2.23 \\
\hline Bintulu & 0.13 & 0.02 & 0.17 & 0.06 & 0.10 & 0.01 & 0.18 & 0.07 & 0.10 & 0.01 & 0.18 & 0.07 \\
\hline Limbang & 0.89 & 0.74 & 0.76 & 0.73 & 1.11 & 0.86 & 0.90 & 0.90 & 1.53 & 1.06 & 1.22 & 1.38 \\
\hline \multicolumn{13}{|l|}{$\mathrm{T}_{\min }\left({ }^{\circ} \mathrm{C}\right)$} \\
\hline Kuching & 0.53 & 0.40 & 0.73 & 0.66 & 0.67 & 0.50 & 1.05 & 0.90 & 0.94 & 0.76 & 1.69 & 1.46 \\
\hline Bintulu & 0.14 & 0.11 & 0.20 & 0.13 & 0.14 & 0.10 & 0.21 & 0.13 & 0.16 & 0.11 & 0.23 & 0.12 \\
\hline Limbang & 0.72 & 1.24 & 1.01 & 0.35 & 1.05 & 1.80 & 1.43 & 0.48 & 1.91 & 3.10 & 2.49 & 0.81 \\
\hline \multicolumn{13}{|c|}{ Precipitation (\%) } \\
\hline Kuching & -5.6 & -0.6 & 5.5 & 6.1 & -4.4 & 0.4 & 7.3 & 7.7 & -6.8 & -2.2 & 6.8 & 9.1 \\
\hline Bintulu & -14.2 & 10.4 & 9.8 & -0.7 & -14.5 & 9.0 & 10.1 & 2.3 & -18.7 & 8.3 & 15.9 & 2.9 \\
\hline Limbang & 7.7 & 11.4 & 14.4 & 7.2 & 8.0 & 9.2 & 15.0 & 6.7 & -1.3 & 5.1 & 7.9 & 5.2 \\
\hline
\end{tabular}


and to $0.76^{\circ} \mathrm{C}, 0.90^{\circ} \mathrm{C}$ and $1.22^{\circ} \mathrm{C}$ at Limbang, under the RCP2.6, RCP4.5 and RCP8.5 scenarios, respectively, when compared with the baseline period of 1976-2000. The $\mathrm{T}_{\min }$ is also projected to increase in future under the all RCPs, as shown in Table 5. Precipitation at Kuching is projected to decrease during DJF, increase during JJA and SON but to remain the same as the historical period during MAM. At Bintulu, the precipitation is also projected to decrease during DJF, increase during MAM and JJA but to remain the same during SON. At Limbang, the precipitation is projected to increase during all seasons under all RCPs by the end of the twentyfirst century, as shown in Fig. 3 and Table 7.

\section{CONCLUSIONS}

Sarawak is the wettest state in Malaysia and receives up to $5 \mathrm{~m}$ of precipitation per year. In the present study, the impact of climate change on temperature and precipitation was assessed at three different locations in the state. The study concluded that the surface temperature is projected to increase in future in all selected places in Sarawak under all selected RCPs. This coincides with the findings of other regional studies, i.e. [14, 21].

The annual precipitation at Kuching and Bintulu is projected to remain unchanged under all future climate scenarios; it coincides with [22] who studied future precipitation changes over Batang Ai catchment in Sarawak, where projected future precipitation is likely to be unchanged. However, a seasonal shift is expected at these locations, with a projection of less precipitation during DJF and more during JJA. On the other hand, Limbang is projected to have more precipitation during every season under all RCPs in future, when comparing the period of 2071-2100 with that of 1981-2010.

This study used precipitation and temperature data from three stations in different regions of the Malaysian state of Sarawak. It is recommended that more stations from each region be included to investigate any uncertainty associated with the data used. The temperature projection is limited by the unavailability of data across the state; however, the precipitation projection could be further expanded with the inclusion of more rainfall stations in each region.

In this study, only CanESM2 GCM output from the Coupled Model Intercomparison Project Phase 5 (CMIP5) was used for the future projection of precipitation, $\mathrm{T}_{\max }$ and $\mathrm{T}_{\min }$. It is recommended to include a few other CMIP5 models for projection and to adopt a mean ensemble of selected models to minimize the uncertainty associated with a single model projection.

\section{ACKNOWLEDGEMENT}

This study was funded by Sarawak Energy Berhad, Malaysia, under a climate change research project. The authors would like to express their thanks to the Department of Irrigation and Drainage, Sarawak (DID), for providing the relevant historical precipitation and temperature data.

\section{REFERENCES}

[1] IPCC, Summary for policymakers. In: Climate Change 2013: The Physical Science Basis. Contribution of Working Group I to the Fifth Assessment Report of the Intergovernmental Panel on Climate Change, eds T.F. Stocker, D. Qin, G.-K. Plattner, M. Tignor, S.K. Allen, J. Boschung, A. Nauels, Y. Xia, V. Bex \& P.M. Midgley, Cambridge University Press, Cambridge, United Kingdom and New York, NY, USA, 2013. 
[2] Hsu, P.C., Li, T., Luo, J.J., Murakami, H., Kitoh, A. \& Zhao, M., Increase of global monsoon area and precipitation under global warming: A robust signal? Geophysical Research Letters, 39(6), 2012. https://doi.org/10.1029/2012GL051037

[3] Lau, W.K.M., Wu, H.T. \& Kim, K.M., A canonical response of precipitation characteristics to global warming from CMIP5 models. Geophysical Research Letters, 40(12), pp. 3163-3169, 2013. https://doi.org/10.1002/grl.50420

[4] Lee, J.Y. \& Wang, B., Future change of global monsoon in the CMIP5. Climate Dynamics, 42(1), pp. 101-119, 2012. https://doi.org/10.1007/s00382-012-1564-0

[5] Hassan, M., Du, P., Jia, S., Iqbal, W., Mahmood, R. \& Ba, W., An assessment of the South Asian summer monsoon variability for present and future climatologies using a high resolution regional climate model (RegCM4.3) under the AR5 scenarios. Atmosphere, 6(11), pp. 1833-1857, 2015. https://doi.org/10.3390/atmos6111833

[6] Hasson, S.U., Pascale, S., Lucarini, V. \& Böhner, J., Seasonal cycle of precipitation over major river basins in South and Southeast Asia: a review of the CMIP5 climate models data for present climate and future climate projection. Atmospheric Research, 180, pp. 42-63, 2016. https://doi.org/10.1016/j.atmosres.2016.05.008

[7] The Second National Communication to the Republic of Malawi to the Conference of the Parties (COP) of the UNFCCC. Ministry of Natural Resources and Environment, Malaysia, 2011.

[8] Ahmed, K.F., Wang, G., Silander, J., Wilson, A.M., Allen, J.M., Horton, R. \& Anyah, R., Statistical downscaling and bias correction of climate model outputs for climate change impact assessment in the U.S. northeast. Global and Planetary Change, 100, pp. 320-332, 2013. https://doi.org/10.1016/j.gloplacha.2012.11.003

[9] Cañón, J., Domínguez, F. \& Valdés, J.B., Downscaling climate variability associated with quasi-periodic climate signals: a new statistical approach using MSSA. Journal of Hydrology, 398(1-2), pp. 65-75, 2011.

https://doi.org/ 10.1016/j.jhydrol.2010.12.010

[10] Yin, C., Li, Y., Ye, W., Bornman, J.F. \& Yan, X., Statistical downscaling of regional daily precipitation over southeast Australia based on self-organizing maps. Theoretical and Applied Climatology, 105(1), pp. 11-26, 2010. https://doi.org/10.1007/s00704-010-0371-y

[11] Timbal, B., Fernandez, E. \& Li, Z., Generalization of a statistical downscaling model to provide local climate change projections for Australia. Environmental Modelling \& Software, 24(3), pp. 341-358, 2009. https://doi.org/10.1016/j.envsoft.2008.07.007

[12] Hussain, M., Yusof, K.W., Mustafa, M.R. \& Afshar, N.R., Application of statistical downscaling model (SDSM) for long term prediction of rainfall in Sarawak, Malaysia. WIT Transactions on Ecology and the Environment, 196, pp. 269-278, 2015. https://doi.org/ 10.2495/wrm150231 
[13] Mahmood, R. \& Babel, M.S., Future changes in extreme temperature events using the statistical downscaling model (SDSM) in the trans-boundary region of the Jhelum river basin. Weather and Climate Extremes, 5-6, pp. 56-66, 2014. https://doi.org/10.1016/j.wace.2014.09.001

[14] Hassan, Z., Shamsudin, S. \& Harun, S., Application of SDSM and LARS-WG for simulating and downscaling of rainfall and temperature. Theoretical and Applied Climatology, 116(1), pp. 243-257, 2014. https://doi.org/10.1007/s00704-013-0951-8

[15] Chu, J.T., Xia, J., Xu, C.Y. \& Singh, V.P., Statistical downscaling of daily mean temperature, pan evaporation and precipitation for climate change scenarios in Haihe River, China. Theoretical and Applied Climatology, 99(1), pp. 149-161, 2010. https://doi.org/10.1007/s00704-009-0129-6

[16] Dibike, Y.B. \& Coulibaly, P., Validation of hydrological models for climate scenario simulation: The case of Saguenay watershed in Quebec. Hydrological Processes, 21(23), pp. 3123-3135, 2007. https://doi.org/10.1002/hyp.6534

[17] Wilby, R.L., Dawson, C.W. \& Barrow, E.M., SDSM - a decision support tool for the assessment of regional climate change impacts. Environmental Modelling and Software, 17(2), pp. 147-159, 2002. https://doi.org/10.1016/S1364-8152(01)00060-3

[18] Mahmood, R. \& Babel, M.S., Evaluation of SDSM developed by annual and monthly sub-models for downscaling temperature and precipitation in the Jhelum basin, Pakistan and India. Theoretical and Applied Climatology, 113(1), pp. 27-44, 2012. https://doi.org/10.1007/s00704-012-0765-0

[19] Huang, J., Zhang, J., Zhang, Z., Xu, C., Wang, B. \& Yao, J., Estimation of future precipitation change in the Yangtze River basin by using statistical downscaling method. Stochastic Environmental Research and Risk Assessment, 25(6), pp. 781-792, 2011. https://doi.org/10.1007/s00477-010-0441-9

[20] Mahmood, R., Jia, S. \& Babel, M., Potential impacts of climate change on water resources in the Kunhar River Basin, Pakistan. Water, 8(1), p. 23, 2016. https://doi.org/10.3390/w8010023

[21] Amin, M.Z.M., Shaaban, A.J., Ohara, N., Kavvas, M.L., Chen, Z.Q., Kure, S. \& Jang, S., Climate change assessment of water resources in Sabah and Sarawak, Malaysia, based on dynamically-downscaled GCM projections using a regional hydroclimate model. Journal of Hydrologic Engineering, 21(1), 2016. https://doi.org/10.1061/(ASCE)HE.1943-5584.0001242

[22] Hussain, M., Nadya, S., Yusof, K.W. \& Mustafa, M.R., Potential impact of climate change on inflows to the Batang Ai reservoir, Malaysia. International Journal on Hydropower \& Dams, pp. 44-48, 2017. 